\title{
The Effect of the Internationalization of the Markets in the European Union Through the Added Value
}

\author{
Carmen Elena Stoenoiu \\ Technical University of Cluj-Napoca \\ Ciprian Cristea \\ Technical University of Cluj-Napoca \\ Florica Mioara Serban \\ Technical University of Cluj-Napoca
}

In this study, an analysis was made of added value from each EU27 economy as a result of the internationalization of the markets, starting from the activity fields in the economy that contribute to obtaining the added value. Thus, a ranking of the countries according to the size of the added value was obtained, an analysis of the changes in activity level in 2017 compared to 2010 and a comparative analysis of the value-added structure between the EU27 and Romania. Finally, a classification of the countries was obtained according to the added value generated by each person employed, at the level of 2017 and it was observed that this indicator shows us the efficiency with which each country manages to value the processes and activities, so that the difference between what produce and what it consumes be high as possible.

Key words: efficiency, performance, internationalization

\section{INTRODUCTION}

The phenomenon of globalization allowed the internationalization of the operational field that brought with it: volume savings, global market information and product development but also flexibility (Madsen, 2005; Mockaitis et al., 2006). To determine if this internationalization produces more advantages than disadvantages, many specialists have studied this phenomenon, but the studies have remained quite empirical. What can be said is that the expanding companies strategically locate their manufacturing organizations and facilities. The challenges of these companies are related to the configuration of the development practices and the organizational and technological integration, as the companies internationalize their markets and operations (O'Brien and David, 2014). Starting from the product life cycle it is considered that the new business will take into account the evolution stages that mainly focus on three directions: the development of new products in the advanced industrial countries, the expansion by identifying markets in countries other than the country of origin and subsequently mass production and marketing in less developed countries (Vernon, 1986; Stonebaker and Liao, 2006). 
With the expanding globalization, the role of innovation has increased, so that organizations are called to define the "rules of the game", to influence the structures and processes, thus allowing to obtain an environment conducive to development (Yamakawa et al., 2008). The differences existing in the level of government policies, education and research, affect the quality and quantity of inputs and outputs, this being reflected by differences related to the availability of technologies, knowledge, intangible assets, ultimately leading to international differences in organizational development [Hoskisson et al., 2013]. By internationalization large companies can create branches in other countries, which from the point of view of institutional development produce benefits for both countries, these benefits being often more significant for the parent company (Michailova and Mustaffa, 2012). Thus, the subsidiaries act as absorbers creating capacities, which in turn accumulate and create value, having access to existing structures and knowledge that are continuously adapting (Teece, 2014; Hedge and Hicks, 2008). The adaptability of international companies is also discussed much more, there are studies that support that this allows the orientation of innovations to market demand, being considered a critical factor affecting performance and survival (Weigelt and Sarkar, 2012). Adaptability is considered to be a feature of firms operating internationally, which allows them to produce better in institutionally developed countries, as they are less uncertain for business than poorly developed countries institutionally (Wu, 2013; Hoskisson et al., 2013).

Differences between countries, in terms of economic development and growth, at the macroeconomic level, have always been debated in the literature, which are often perceived as developmental differences due to the lack of efficiency of processes leading to low economic efficiency and a high production cost. Some authors argue that at the basis of these differences would be the uneven development of the sectors of activity from different countries (Turunen et al., 2011; Atoyan et al., 2013), the lower interest rates and the abundance of liquidities that lead to excessive indebtedness public and private sector (Ferrero, 2012; Aizenman and Jinjarak, 2009) or as a result of differences between countries as a result of fiscal policies adopted (Hanousek and Shamshur, 2011; Kouki and Said, 2012).

The issue of sustainability or sustainable development in the conditions of globalization is also discussed in terms of the problems it entails as a result of regulations, behavior, value chains, daily routines of users, consumption patterns, economic incentives, perceptions, attitudes and values (Grunwald, 2014), but also in terms of the escalating effect of inequalities between countries as a result of large multinational corporations, primarily oriented towards profit and less towards welfare (Pawlowski, 2012).

The purpose of this study was to establish the performance of the countries of the EU27, by analyzing the added value obtained by them for eight years (2010-2017). For this analysis, the values related to all the activity fields that bring added value at the country level were studied and a ranking of the countries was obtained according to the obtained performance. As added value is a macroeconomic indicator that allows for global comparisons, the weight held in total EU27 was calculated for each country in relative size, then the added value indices were calculated for each year (2010 being the reference) for all the fields of activity. Finally, value-added indicator was calculated on the person employed at the country level, obtaining the average value at country level of the indicator that allows comparisons between countries being able to see what is the contribution of each person employed in the added value from that country.

\section{MATERIAL AND METHOD}

In order to carry out this study, the value-added was used as a reference indicator, this indicator being a macroeconomic result indicator. The value-added allowed measurement of the difference between the value of the production and the intermediate consumption underlying the production, less the value of the subsidies to production and the taxes and duties, according to the data provided by the Eurostat database. In this study, an exploratory analysis was carried out for the 27 EU countries, over the years 2010-2017, according to data provided by the Eurostat database (data collection was carried out on 22.01.2020). In the analysis were comprised 27 EU countries (Belgium (BE), Bulgaria (BG), Czech Republic (CZ), Denmark (DK), Germany (DE), Estonia (EE), Ireland (IE), Greece (EL), Spain (ES), France (FR), Croatia (HR), Italy (IT), Cyprus (CY), Latvia (LV), Lithuania (LT), Luxembourg (LU), Hungary (HU), Netherlands (NL), 
Austria (AT), Poland (PL), Portugal (PT), Romania (RO), Slovenia (SI), Slovakia (SK), Finland (FI), Sweden (SE), United Kingdom (UK).

The value-added indicator (expressed in millions of euros) was chosen for the study because it is considered that through it one can observe the efficiency and the result recorded at the country level and implicitly the development level of the processes and activities. This indicator allows to observe the level of development of some branches of activity in the economy of each country regarding the complexity of the economic goods or services that it generates. It is considered that the more complex the goods or the services and, consequently with a higher degree of processing, the higher the weight of the value produced and the lower the weight of the intermediate consumption, which results in a higher economic efficiency.By means of the value-added indicator the weight of each country in the total EU27 was calculated, on each activity field, so that the evolution of each country can be observed on each indicator separately but also for the total value-added at the country level.

In Table 1 are presented the indicators that were the object of the study and which contributes to the measurement of added value at the level of each country on the 12 types of activities in the economy.

TABLE 1

\section{SUMMARY OF THE INDICATORS THAT MAKE UP THE ADDED VALUE}

\begin{tabular}{|c|l|c|c|}
\hline No. & \multicolumn{1}{|c|}{ Indicator } & Abb. & Symbol \\
\hline 1 & Accommodation and food services activities & AFSA & I1 \\
\hline 2 & Administrative and support service activities & ASSA & I2 \\
\hline 3 & Construction & C & I3 \\
\hline 4 & Electricity, gas steam and air conditioning supply & EGSACS & I4 \\
\hline 5 & Information and communication & IC & I5 \\
\hline 6 & Manufacturing & M & I6 \\
\hline 7 & Mining and quarrying & MQ & I7 \\
\hline 8 & Professional, scientific and technical activities & PSTA & I8 \\
\hline 9 & Real estate activities & RES & I9 \\
\hline 10 & Transportation and storage & I10 \\
\hline 11 & Water supply: sewerage, waste management and remediation activities & WS & I11 \\
\hline 12 & Wholesale and retail trade, repair of motor vehicles and motorcycles & WRT & I12 \\
\hline
\end{tabular}

The total added value was obtained by summing the added value related to all fields of activity, according to the relation Eq. (1):

$V A=\sum_{n=1}^{12} I_{n}$

Where: VA - value-added, $\mathrm{I}_{\mathrm{n}}$ - indicator symbol (according to Table 1 ), $\mathrm{n}$ - identifier number, $\mathrm{n}=1 \div 12$.

In order to observe the evolution in time of each country, we calculated the indexes based on the chain, using as reference year (base year) the year 2010. In order to calculate each index, each value of each indicator of each indicator was reported at the value corresponding to the reference year of that indicator, according to the relation Eq. (2).

$I_{n i}=\frac{\text { Indicator value from year }}{\text { Indicator value from year }}$

Where: $\mathrm{n}$ - the number associated with the indicator $(\mathrm{n}=1 \div 12), \mathrm{i}$ - the number associated with the index with the base in the chain for the calculated year $(i=1 \div 7)$. For example, in Eq. (3), $I_{11}$ represents the index for the field of activity Accommodation and food services activities (AFSA), relating the value for 2011 (year 1) to the value for 2010 (year 0): 
$I_{11}=\frac{V a l A F S A_{1}}{V a l A F S A_{0}}$

Subsequently, a comparative analysis of the value-added structure related to Romania compared to the average from all EU27 countries was made for 2017. By this we can it was observed if there are significant differences in the structure of the Romanian economy, by activity fields, with compared to the average value recorded in the EU27 countries.

Because the value-added indicator presents different values from one country to another, on the one hand due to the size of each country and on the other hand due to the level of efficiency and technological development but also of institutional development, it was calculated for 2017 the value-added indicator / employed person. For this the following indicators were used: "Population on 1 January [tps00001]" (expressed in number of persons), which multiplied with the indicator "Employment rate by sex, age group 20-64 [t2020_10]" (expressed in\% ), to get the number of people employed in each country.

\section{RESULTS AND DISCUSSION}

\section{Value-added and Their Structure and Evolution}

The added value can be traced through the evolution of its structure, which is given by the economy of each country but also through each field of activity. Figure 1 shows the global added value obtained by the 27 countries in the EU, which resulted from summing the added value from each field of activity.

FIGURE 1

DISTRIBUTION OF VALUE-ADDED AT EU LEVEL

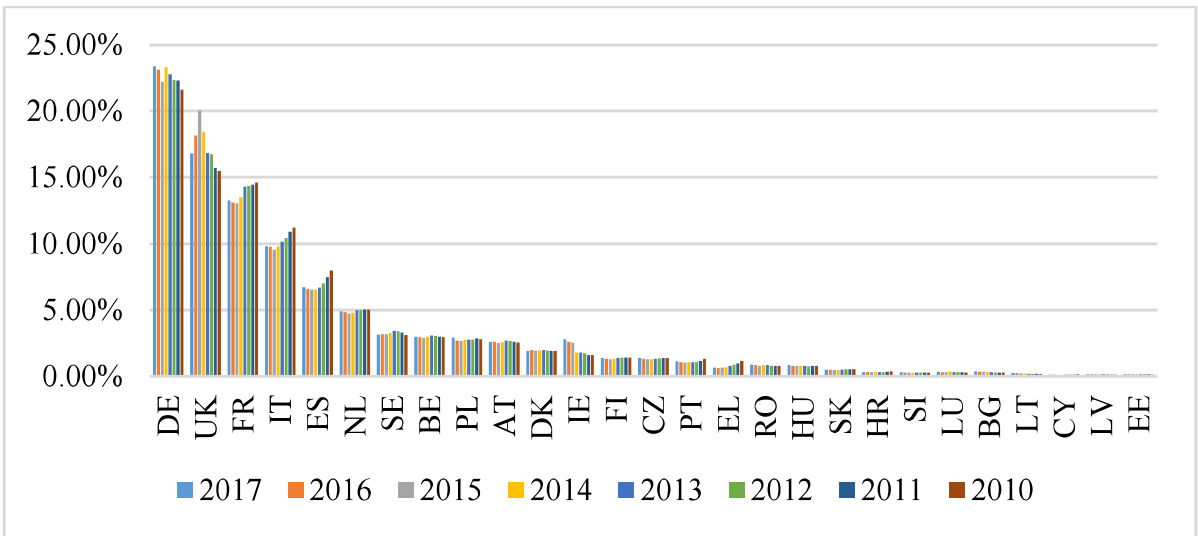

Source: Processed by authors based on data from Eurostat [tin00150]

Analyzing Figure 1 it is found that there are certain changes that have been registered every year from country to country. Thus it is found that the value-added indicator has a tendency to decrease from 2010 to 2017, in some countries such as: United Kingdom, France, Italy, Spain but also to growth trend in the countries such as: Germany, Poland and Ireland. This decrease in value-added can also be explained by the data existing in Table A (from Appendix), where it can be observed that in 2017 compared to 2010 in France the decrease is given by the values obtained from the indicators: Mining and Quarrying (I77: 0.52\%) and Professional, scientific and technical activities (I87: 0.94\%), in Italy the decrease is given by the low values of the indicators: Construction (I37: 0.81\%), Information and communication (I57: 0.95\%), Mining and Quarrying ( I77: 0.41\%), Professional, scientific and technical activities (I87: 0.99\%), Real estate activities (I97: $0.94 \%$ ), and in Spain the decrease of the added value is given by the decrease at the indicators: Construction (I37: 0.61\%) and Information and communication (I57: 0.99\%). From Figure 1 it is found that the highest share of the value-added in total EU27, in 2017, is obtained by Germany (23.38\%), 
United Kingdom (16.80\%), France (13.25\%), Italy (9.79\%) and Spain (6.71\%), and values below 5\% in the other countries.

From the analysis of activity it can be seen that all activity fields are present in every country in EU27. On the first four places in the fields of activity presented are located: Accommodation and food services activities (I1), Administrative and support service activities (I2), Information and communication (I5), and Professional, scientific and technical activities (I8). In the specified fields of activity it can be seen that the best results was registrated are in the following countries: United Kingdom, Germany and France. From the analysis of folow activities: Construction (I3), Electricity, gas steam and air conditioning supply (I4), Real estate activities (I9), Transportation and storage (I10) and Wholesale and retail trade, repair of motor vehicles and motorcycles (I12) we can be seen that the first three places are occupied by: Germany, United Kingdom and France. From the analysis of activity Manufacturing (I6) it can be seen that the first three places are the countries: Germany, Italy and France. From the analysis of the activity Mining and quarrying (I7) it can be seen that the first three places are the countries: United Kingdom, Poland, Netherlands. From the analysis of activity Water supply: sewerage, waste management and remediation activities (I11) it can be seen that the first three places are the countries: Germany, United Kingdom and Italy.

\section{Distribution of EU27 Countries According to the Evolution of Indices}

Because maintaining economic stability and proportionality on activity domains is considered to be a premise for each country, in this study we calculated indices with base in chain, which allow to measure the evolution of each country through the field of activity and the year of study (according to Table A, in Appendix). The analysis of these indices shows that at all fields of activity, in the years 2011 and 2012 compared to 2010 smaller changes were recorded, the most significant being from year 2015 as far as 2017 compared to 2010 .

From the analysis of Table A (from Appendix), it is found that in 2017, at the indicator Accommodation and food services activities the biggest increases compared to 2010 were registered in Lithuania (2.82), Estonia (2.36) and Romania (2.21). At the Administrative and support service activities, the biggest increase compared to 2010 was registered in the countries: Lithuania (2.82), Romania (2.38) and Bulgaria (2.32). In the activity of Construction the biggest increases were registered in the countries: Ireland (5.11), Lithuania (2.29) and Estonia (2.26). In the activity of Electricity, gas steam and air conditioning supply the biggest increases were registered in the countries: Luxembourg (1.58), Denmark (1.37) and France and Bulgaria (1.35). In the Information and communication activity, the biggest increases were made in the countries: Ireland (1.96), Latvia (1.81) and Estonia (1.75). In Manufacturing activity the biggest increases were registered in the countries: Ireland (2.83), Bulgaria (1.88) and Lithuania (1.82). Mining and quarrying activity saw the largest increases in the countries: Greece (2.18), Luxembourg (1.72) and Estonia (1.54). In Professional, scientific and technical activities the biggest increases were registered in the countries: Lithuania (2.13), Ireland (2.06) and Luxembourg (2.03). In the Real estate activities, the biggest increases were registered in the countries: Ireland (4.63), Estonia (2.81) and Greece (2.56). In the activity of Transportation and storage the biggest increases were registered in the countries: Lithuania (2.12), Bulgaria (1.57) and Hungary (1.5). In the water supply activity: sewerage, waste management and remediation activities, the biggest increases were registered in the countries: Ireland (2.16), Lithuania (1.73), Denmark (1.49) and Sweden (1.48). In the activity Wholesale and retail trade, repair of motor vehicles and motorcycles the biggest increases were registered in the countries: Lithuania (2.11), Romania (1.76) and Bulgaria (1.73)

\section{Comparative Analysis of the Value-Added Structure}

As in almost all countries there are increasing values from year to year, it was considered important to study the extent to which the proportions at the Romanian level are maintained and at level of activity areas compared to the one registered at EU27 level. For this, in Figure 2 are presented comparatively the distributions of the indicators by component that determine the value structure added from EU27 and Romania. 
FIGURE 2

DISTRIBUTION OF VALUE-ADDED AT THE LEVEL OF 2017

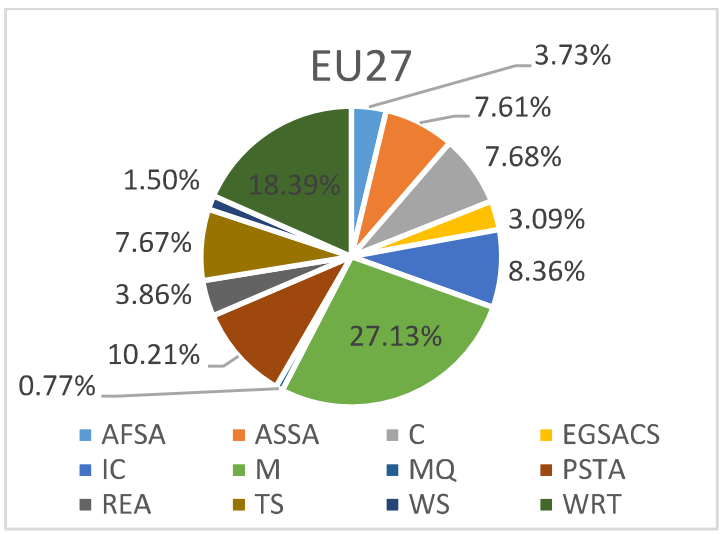

(a)

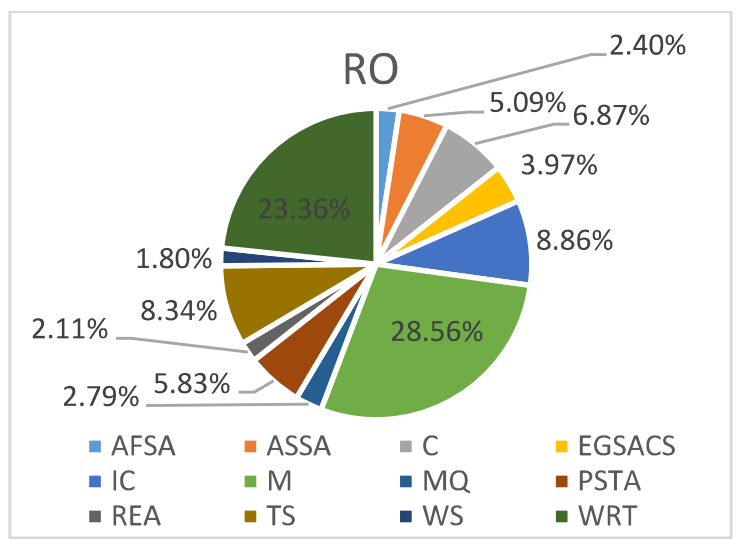

(b)

Source: Processed by authors based on data from Eurostat [tin00150]

From analysis of Figure $2 \mathrm{a}$ we can see that at EU27 level the highest weight at added value level is held by the activity: (I1) Manufacturing (M), followed by the activities: (I2) Wholesale and retail trade, repair of motor vehicles and motorcycles (WRT), (I3) Professional, scientific and technical activities (PSTA), (I4) Information and communication (IC), (I5) Construction (C), (I6) Transportation and storage (TS), (I7) Administrative and support service activities (ASSA), (I8) Real estate activities (REA), (I9) Accomodation and food service activities (AFSA), (I10) Electricity, gas steam and air conditioning supply (EGSACS), (I11) Water supply : severage, waste management and remediation activities (WS) and (I12) Mining and quarying (MQ). From analysis of Figure $2 b$, at the level of Romania, it is found that the highest weight of added values is obtained at the activities mentioned in that order: (I1), (I2), (I4), (I6), (I5), (I3), (I7), (I10), (I12), (I9), (I8), (I11). Because at the basis of the economic performance in a country is the efficiency registrated, it is considered that the top industries are the ones that determine the progress and implicitly the level of development, due to the high added value. Starting from these premises (I3) Professional, scientific and technical activities (PSTA) is considered to be in Romania the most deficient compared to the average value registrated in EU27 level.

From analysis of Figure 2 (comparing Figure $2 \mathrm{a}$ with $2 \mathrm{~b}$ ) it is found that the activities in Romania compared to those in the countries EU27 are close in weight, there some small differences. Thus, in Romania there were lower values at the level of value-added to the following activities: Accomodation and food services activities (AFSA) of $-1.33 \%$, Administrative and support service activities (ASSA) of $-2.52 \%$, Construction (C) of $-0.81 \%$, Professional, scientific and technical activities (PSTA) of $-4.38 \%$, Real estate activities (REA) of $-1.75 \%$ and higher values for Electricity, gas steam and air conditioning supply (EGSACS) of $+0.88 \%$, Information and communication (CI) of $+0.5 \%$, Manufacturing $(\mathrm{M})$ of $+1.43 \%$, Mining and quarying (MQ) of $+2.02 \%$, Transportation and storage (TS) of $+0.67 \%$, Water supply: severage, waste management and remediation activities (WS) of $+0.3 \%$, Wholesale and retail trade, repair of motor vehicles and motocycles (WRT) of $+4.97 \%$. It is found that the added value obtained from the activity of wholesale, retail and repair of vehicles (WRT) brings a greater contribution than that registered in EU27, followed by the activity Mining and quarying (MQ) and Manufacturing (M).

\section{Added Value in Relation to the Employed Population}

Figure 3 shows the distribution of added value per person employed at the level of 2017, which shows surplus value due to efficiency and complexity of process at the level of each activity area. 


\section{DISTRIBUTION OF VALUE-ADDED PER EMPLOYED PERSON AT THE LEVEL OF 2017}

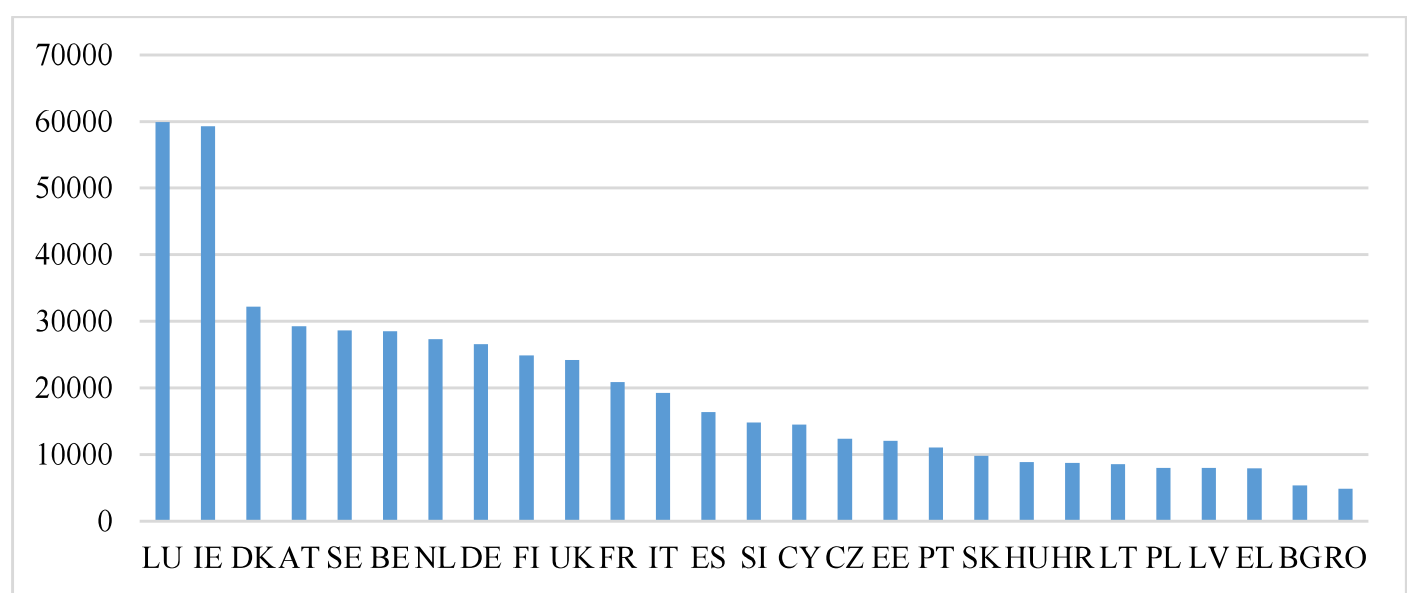

Source: Processed by authors based on data from Eurostat [tin00150, tps00001, t2020_10]

From analysis of Figure 3 it can be seen that the countries that registered the highest values in terms of efficiency and performance are: Luxembourg, Ireland and Denmark, of which Luxembourg and Ireland recorded the highest values. In Luxembourg the fields of activity that bring the greatest contribution in added value are: Wholesale and retail trade, repair of motor vehicles and motorcycles $(21.04 \%)$, Professional, scientific and technical activities (17.91\%), Manufacturing (12.36\%) and Information and communication (11.65\%). In Ireland, the fields of activity that bring the highest added value are: Manufacturing (47\%), Information and communication (14.08\%), Wholesale and retail trade, Repair of motor vehicles and motorcycles (10.82\%) and Administrative and support service activities ( 8.06\%).

Compared to Luxembourg, the other countries registered much lower values, the difference in size is pretty big compared to the following countries: Denmark (54\%), Austria (49\%), Sweden (48\%), Belgium (48\%), Netherlands (46\%), Germany (44\%), Finland (42\%) and United Kingdom (40\%). On the last three places are Greece (13\%), Bulgaria (9\%) and Romania (8\%)

Although the value-added indicator for Romania increased in 2017 compared to 2010 with 1.67 times (ie $67 \%$, so more than half as value), however, at the level of "added value / employed person" indicator are recorded the lowest value which tells us that the gap between production and intermediate consumption is very small, which means that the efficiency and complexity of the processes are low.

\section{CONCLUSIONS}

By analyzing the value-added through the structure component we have obtained information related to how each activity participates, respectively brings its contribution, in the economy of each country. Thus the analysis shows us that the highest weights by activity fields are: Mining and quarying (UK: $33.08 \%$ ), Manufacturing (DE: 29.39\%), Real estate activities (DE: 28.19\%), Professional, scientific and technical activities (UK: 26.31\%), Administrative and support service activities (UK: 23.84\%), Water supply: severage, waste management and remediation activities (DE: 22.97\%), Information and communication (UK: 22.76\%), Wholesale and retail trade (DE: 22.28\%), Accomodation and food service activities (UK: 19.94\%), Electricity, gas steam and air conditioning supply (DE: 19.86\%), Transportation and storage (DE: 19.57\%), Construction (DE: 19.18). The value-added globally reaches the highest values in following countries: Germany (23.38\%), United Kingdom (16.80\%), France (13.25\%).

When calculating the indices for 2017 compared to 2010, it was found that each country registered significant changes, in the following successive order: Construction in Ireland (5.11), Real estate activities the most in Ireland (4.63), Manufacturing in Ireland (2.83), Accommodation and food service activities in Lithuania (2.82), Administrative and support service activities in Lithuania (2.82), Mining and quarrying 
in Greece (2.18), Water supply: sewerage, waste management and remediation activities , in Ireland (2.16), Professional, scientific and technical activities in Lithuania (2.13), Transportation and storage in Lithuania (2.12), Wholesale and retail trade, repair of motor vehicles and motorcycles in Lithuania (2.11), Information and communication in Ireland (1.96) and Electricity, gas steam and air conditioning supply in Luxembourg (1.58).

From the comparative analysis of the added value made in Romania, we can see that on the first three places as weight are the activities: Accommodation and food service activities, Administrative and support service activities and Electricity, gas steam and air conditioning supply, activities that are present in EU27 on places 1,2 and 4 .

From the analysis of the added value in relation to the employed population, it is found that the value registrates in Luxembourg and Ireland are two times higher than the value registrated in the following countries (Denmark, Austria, Sweden, Belgium and the Netherlands). This allows us to conclude that these countries have the highest level of efficiency of processes and activities. We can say that internationalization has had beneficial effects for those economies that have adapted the best to development practices and organizational and technological integration.

\section{REFERENCES}

Aizenman, J., \& Jinjarak, Y. (2009). Current account patterns and national real estatemarkets? Journal of Urban Economics, 66(2), 75-89.

Atoyan, R., Manning, J., \& Rahman, J. (2013). Rebalancing: evidence from current account adjustment in Europe. IMF Working Papers. International Monetary Fund.

Ferrero, A. (2012). House Price Booms, Current Account Deficits, and Low Interest Rates. Federal Reserve Bank of New York.

Grunwald, A. (2014). Sustainability research as inter- and trans-disciplinary activity: the case of German Energiewende. Problemy Ekorozwoju, 9(1), 11-20.

Hanousek, J., \& Shamshur, A. (2011). A stubborn persistence: Is the stability of leverage ratios determined by the stability of the economy? Journal of Corporate Finance, 17, 1360-1376.

Hedge, D., \& Hicks, D. (2008). The maturation of global corporate R\&D: Evidence from the activity of U.S. foreign subsidiaries. Research Policy, 37, 390-406.

Hoskisson, R.E., Wright, M., Filatotchev, I., \& Peng, M.W. (2013). Emerging multinationals from midrange economies: The influence of institutions and factor markets. Journal of Management Studies, 50(7), 1295-1321.

Kouki, M., \& Said, H.B. (2012). Capital structure determinants: new evidence from French panel data. International Journal of Business and Management, 7(1), 214-229.

Madsen, T.K. (2005). Internationalization research: the impact of the Carnegie school. Scandinavian Journal of Management, Elsevier, 21(4), 373-384.

Michailova, S., \& Mustaffa, Z. (2012). Subsidiary knowledge flows in multinational corporations: Research accomplishments, gaps, and opportunities. Journal of World Business, 47, 383-396.

Mockaitis, A.I., Vaiginiene, E., \& Giedraitis, V. (2006). The internationalization efforts of Lithuanian manufacturing firms-strategy or luck. Research in International Business and Finance, Elsevier, 20(1), 111-126.

O'Brien, J.P., \& David, P. (2014). Reciprocity and R\&D search: Applying the behavioural theory of the firm to a communitarian context. Strategic Management Journal, 35, 550-565.

Pawlowski, L. (2012). Do the Liberal Capitalism and Globalization Enable the Implementation of Sustainable Development Strategy? Problemy Ekorozwoju, 7(2), 7-13.

Stonebaker, P.W., \& Liao, J. (2006). Supply chain integration: exploring product and environmental contingencies. Supply Chain Management, 11(1), 34-43.

Teece, D.J. (2014). A dynamic capabilities-based entrepreneurial theory of the multinational enterprise. Journal of International Business Studies, 45, 8-37. 
Turunen, J., Harmsen, R.T., \& Bayoumi, T. (2011). Euro Area Export Performance and Competitiveness. IMF Working Papers 11/140. International Monetary Fund.

Vernon, R. (1986). Can US manufacturing come back. Harvard Business Review, 67(30), 112-125.

Weigelt, C., \& Sarkar, M. (2012). Performance implications of outsourcing for technological innovations: Managing the efficiency and adaptability trade-off. Strategic Management Journal, 33(2), 189216.

$\mathrm{Wu}, \mathrm{J}$. (2013). Marketing capabilities, institutional development, and the performance of emerging market firms: A multinational study. International Journal of Research in Marketing, 30(1), 36-45.

Yamakawa, Y., Peng, M.W., \& Deeds, D.L. (2008), What drives new ventures to internationalize from emerging to developed economies? Entrepreneurship Theory and Practice, 32(1), 59-82. 


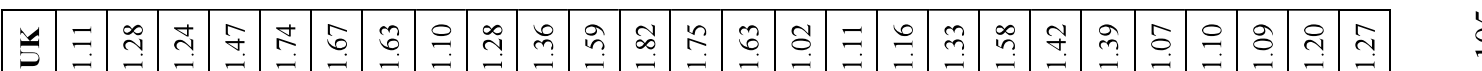

되 0 m

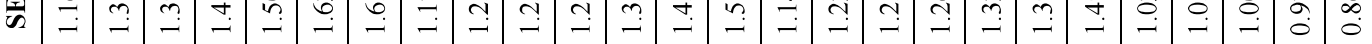

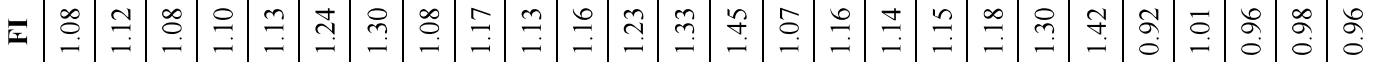

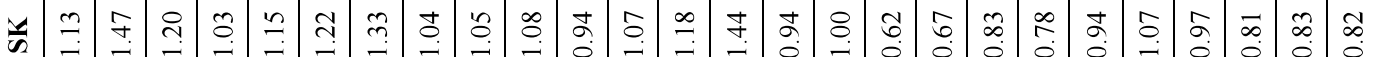

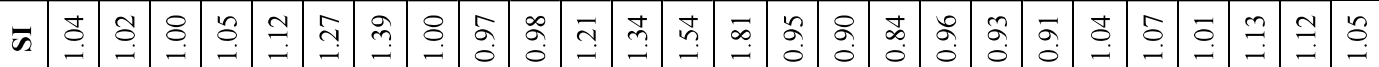

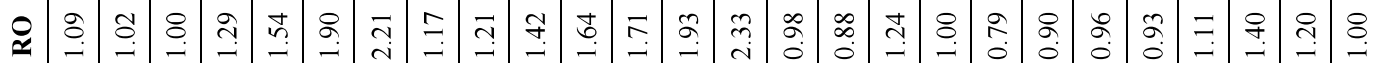

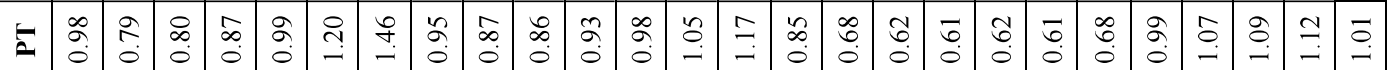

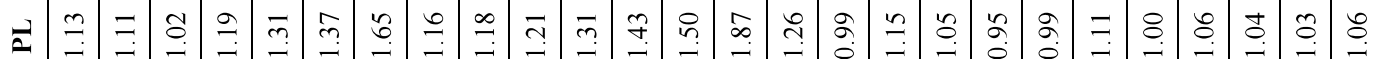

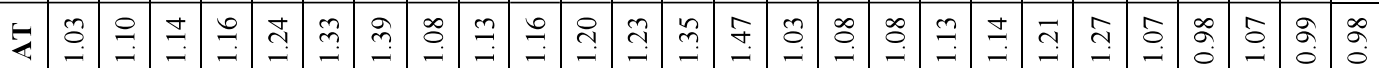

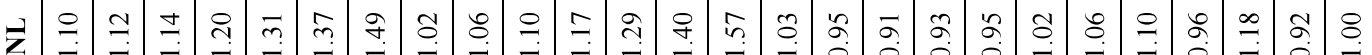

Z

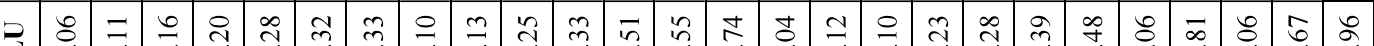

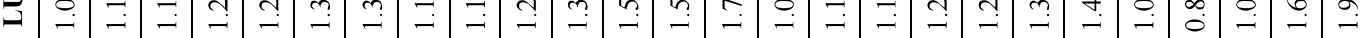

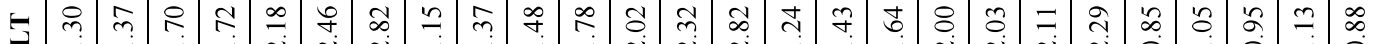

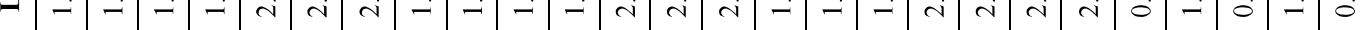

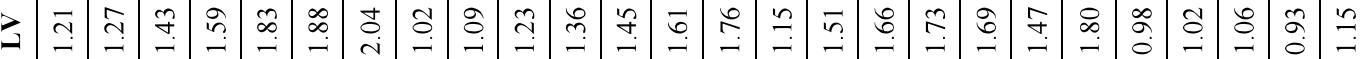

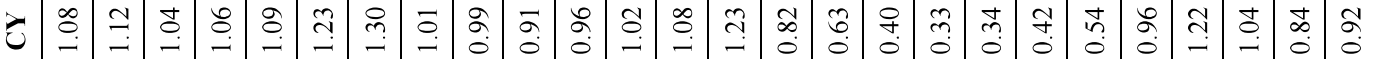

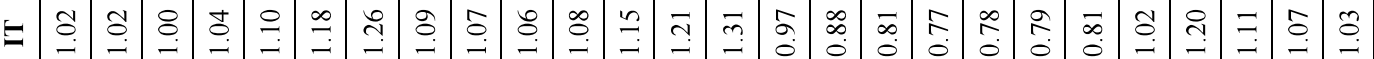

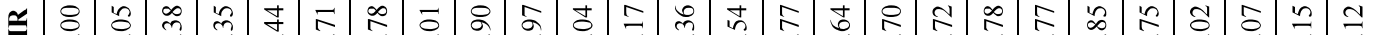

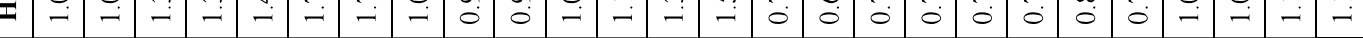

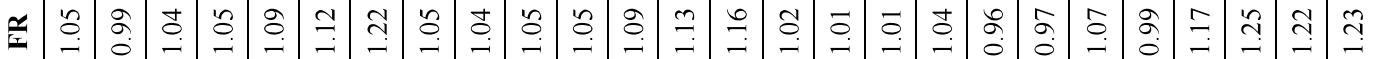

n ప

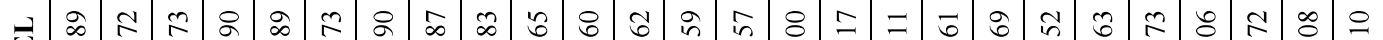

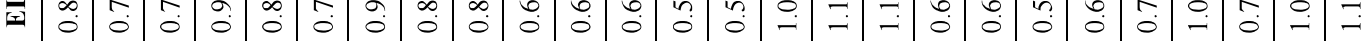

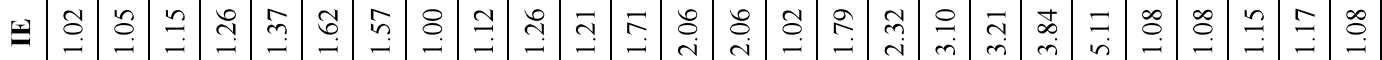

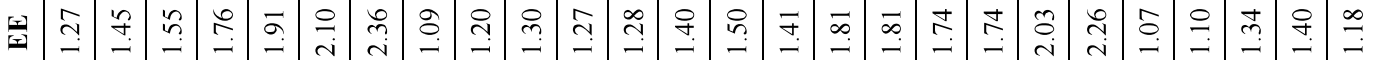

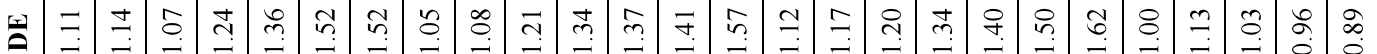

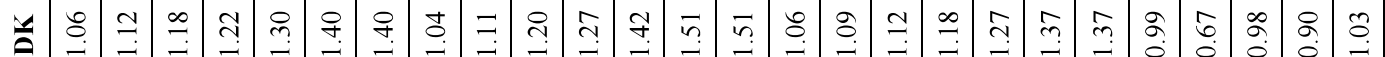

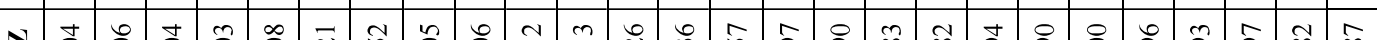

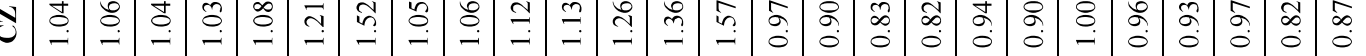

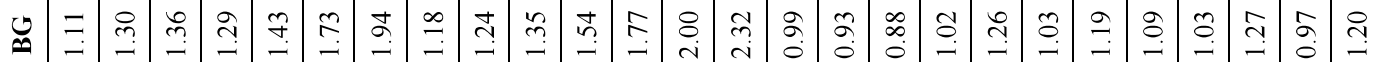

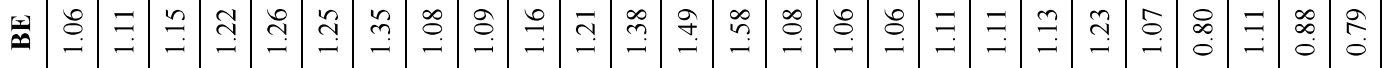

灾

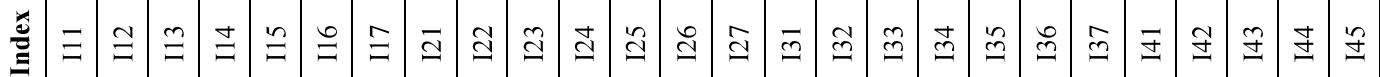




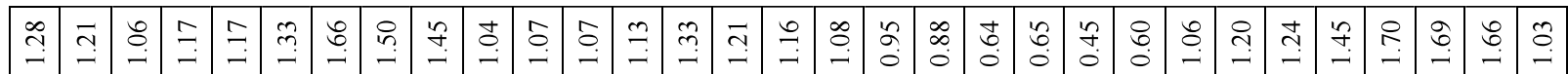
舟 б $\sigma$ o

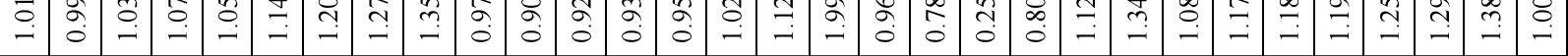

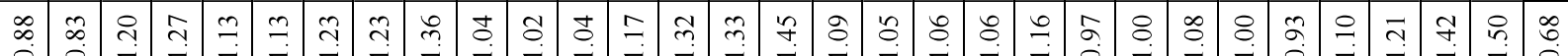
+

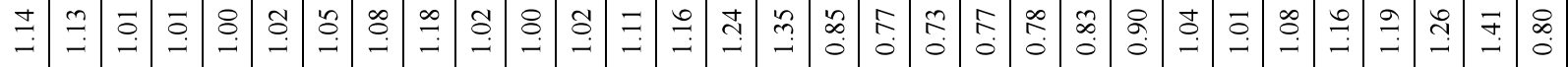

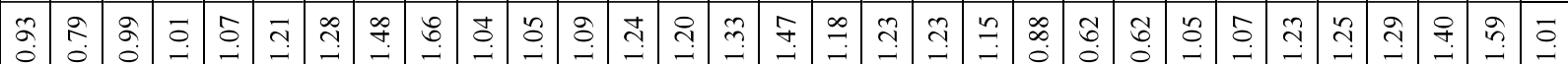

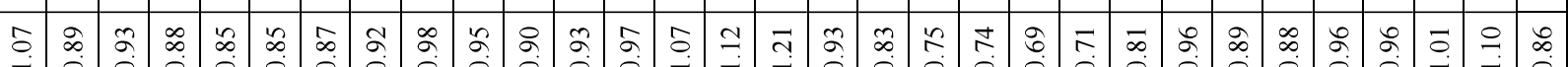

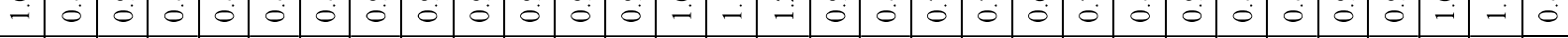
gे

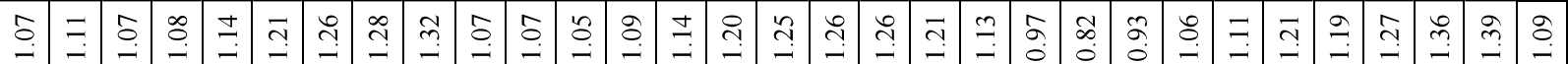

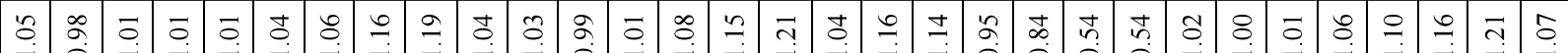

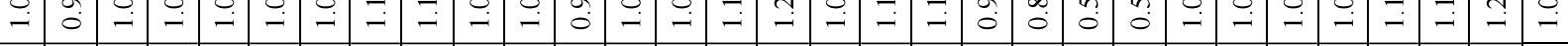

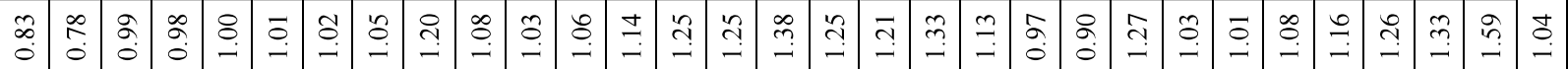
곡 물

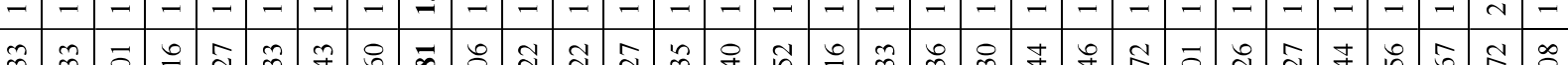

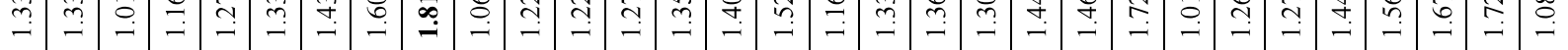

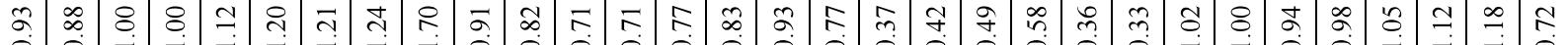

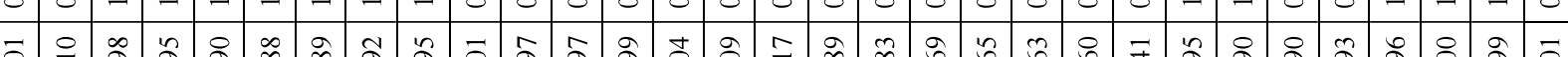

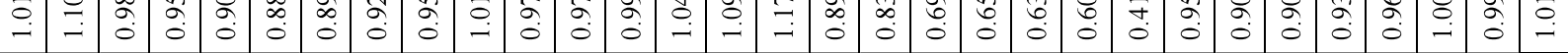

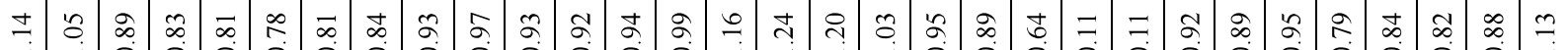

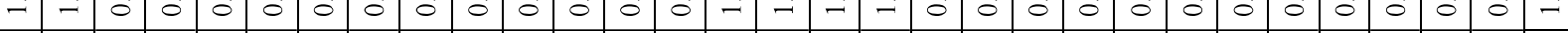

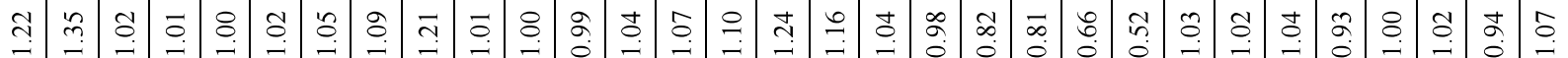

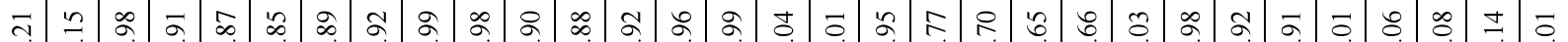

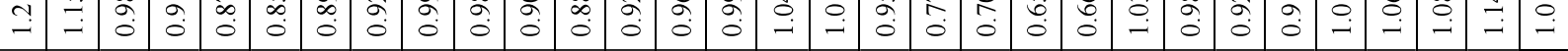

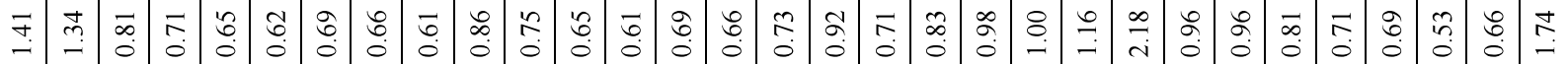
ஸి

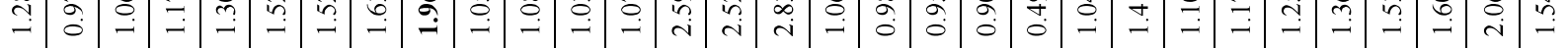
鳥

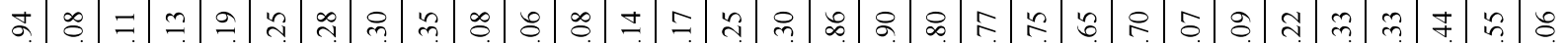

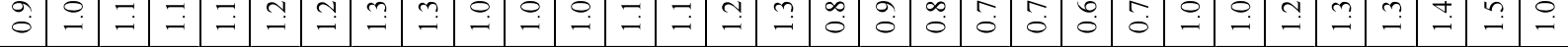

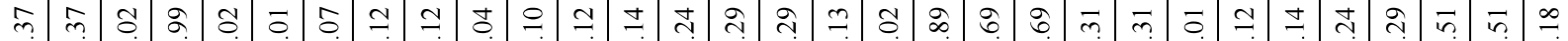

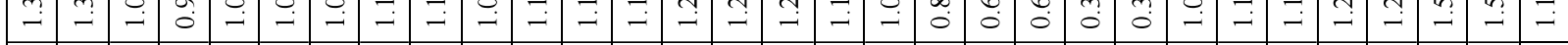
১ 0

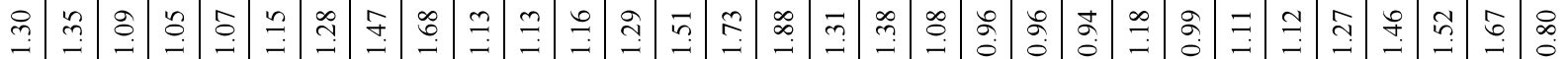
我

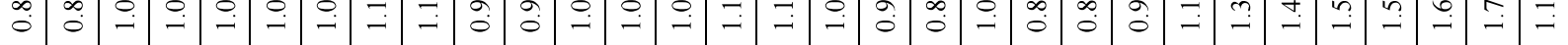

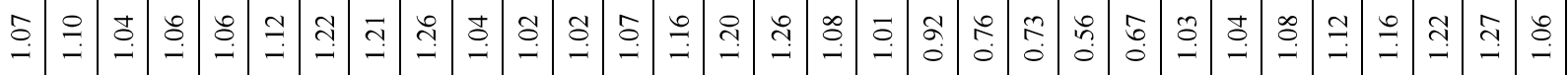

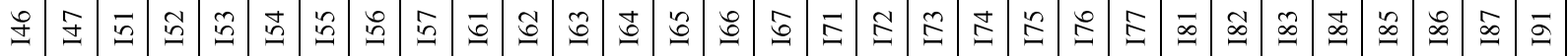




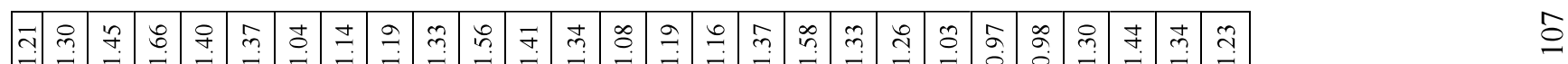

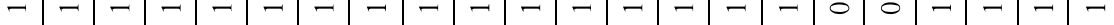
กิ ๆ

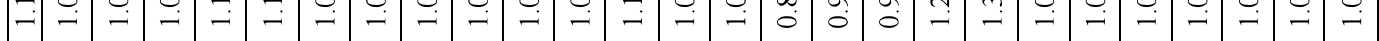
^ \begin{tabular}{lllllllllllllllllllllllllllllllll}
0 & - & 0 & 0 & - & 0 & - & - & - & - & - & - & - & 0 & 0 & 0 & 0 & 0 & 0 & 0 & - & 0 & 0 & 0 & 0 & 0 & 0 \\
\hline
\end{tabular}

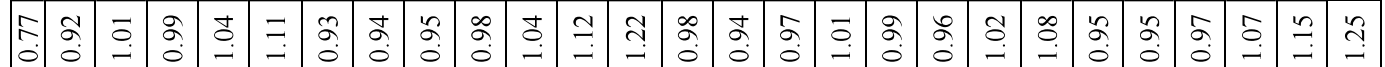
$\cong$ Эำ

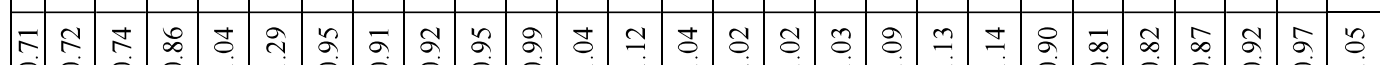

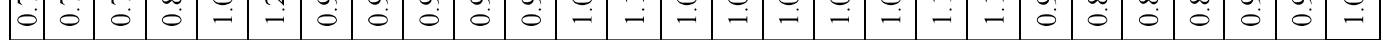

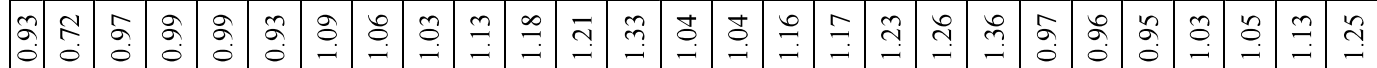
$\cong$ กิ

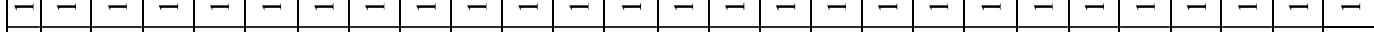
ণิฺָ ఫ

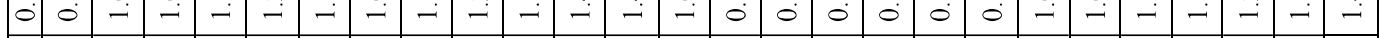

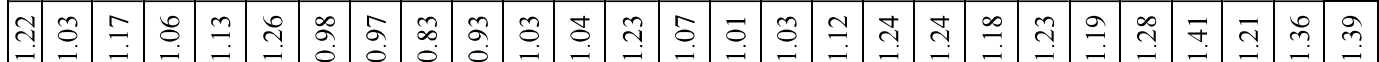
$\stackrel{n}{n}$ ஸุ

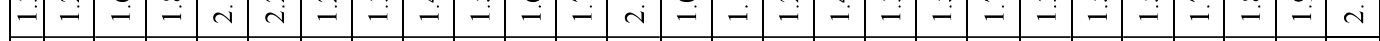
స̦ 16 8 ㅇ

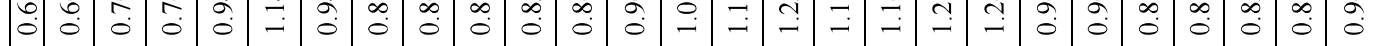

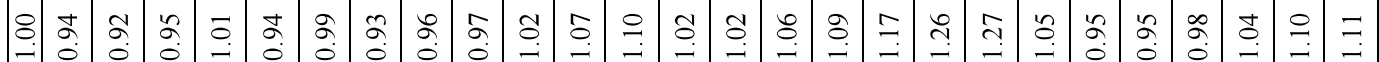

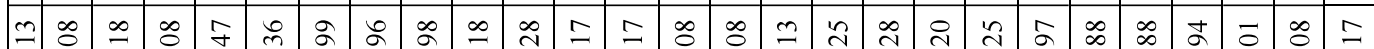
$\exists$ ت ○. ○

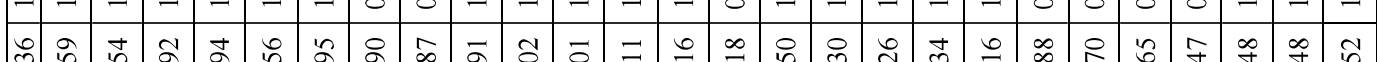

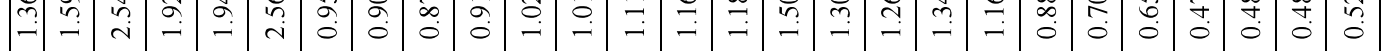

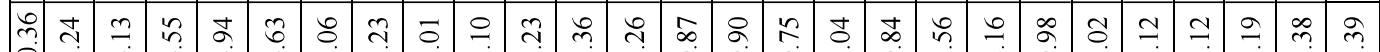

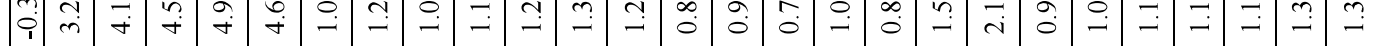

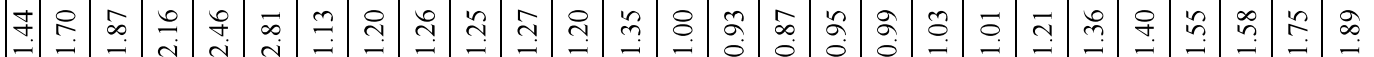

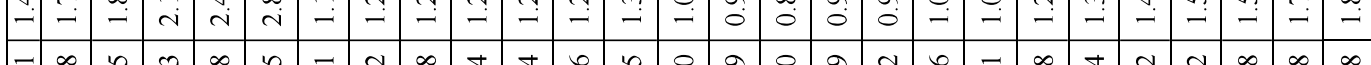

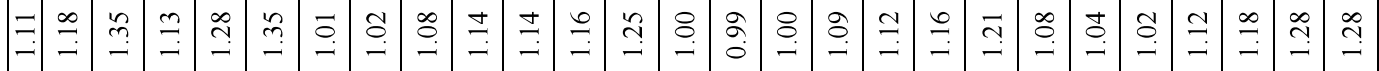

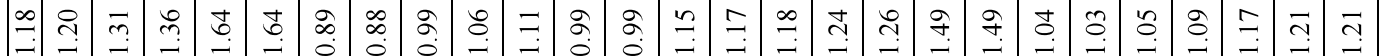

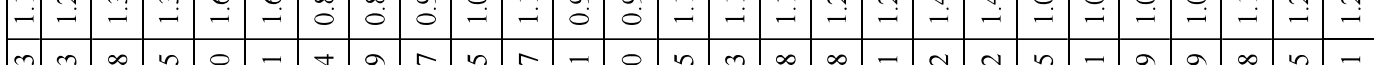
ô そ̊ సิ ป ปุ

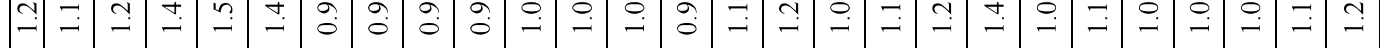

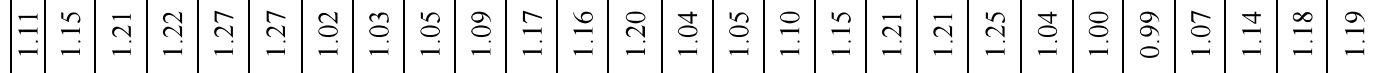

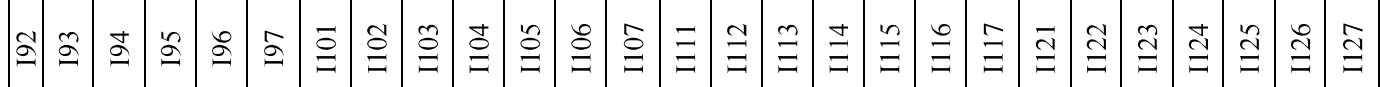

